International Journal of Computer and Information System (IJCIS)

Peer Reviewed - International Journal

Vol : Vol. 02, Issue 01, February 2021

e-ISSN : 2745-9659

https://ijcis.net/index.php/ijcis/index

\title{
Analysis of Adi Soemarmo Solo Airport Parking Payment System
}

\author{
$1^{\text {st }}$ Dwiyana, $2^{\text {nd }}$ Muqorobin \\ ${ }^{1,2}$ Institut Teknologi Bisnis AAS Indonesia Surakarta \\ ${ }^{1,2}$ Jl. Slamet Riyadi No. 361 Windan, Makamhaji, Kartasura, Sukoharjo, Indonesia \\ ${ }^{1}$ sarapertiwi12@gmail.com, ${ }^{2}$ robbyaullah@gmail.com
}

\begin{abstract}
The writing of the Semester Final Project with the title Analysis of the Parking Payment System for Adi Soemarmo Airport Solo was compiled based on the results of observations at the exit gate of Adi Soemarmo Airport Solo. Transactions on parking payments often cause problems due to several factors, especially the time or process is quite long because sometimes the mone yiven is too large then the cashier takes too long to give change, besides that sometimes passengers do not prepare the money they want to pay in advance and often passengers pay in a situation of insufficient money and this causes queues or jams at the gate exit. The research objective given by the author later is to provide the best solution for airport parking payment systems. In addition to making it easier for passengers, this will greatly facilitate cashiers when carrying out work operations. This payment application system is called u-nik or electronic money. Where u-nik functions to transfer the money balance data contained in u-nik to a computer using a system called AINO. So that payments occur without spending additional cash. With the existence of non-cash payment transactions using the AINO system, it is hoped that it can facilitate and provide speed in making parking payment transactions without the need to carry cash.
\end{abstract}

Keywords—Parking, Transactions, Congestion, Decision Support System, AINO.

\section{INTRODUCTION}

At present, technological developments, especially in the field of electronic money, have become an important part of all levels of society in carrying out a payment operation. However, there are still many people who do not understand how easy it is to transact using electronic money.

In the parking payment system for Adi Soemarmo Airport, Solo also follows the development of this technology flow. Likewise with the payment system at the gate exit or exit gate of the airport. This system still runs 2 types of operations, either cash or non-cash. In paying parking, this often creates problems or obstacles because sometimes the money given is too large and then the cashier takes too long to give change, besides that sometimes passengers do not prepare the money they want to pay in advance and often passengers pay in a state of insufficient money, on the payment system cash using banknotes and coins sometimes makes the payment transaction process longer. Not to mention if there are counterfeit bills or torn money.

It is different from the non-cash payment system which is commonly referred to as the u-nik payment system or electronic money. Because if you use this payment system, it is hoped that you can minimize the queues of vehicles that cause congestion and it is also good that cashiers no longer need to count money or exchange disputed money. Therefore it is necessary to develop an understanding of how easy it is to transact using u-nik or electronic money by AINO.

\section{RESEARCH METHODS}

Planning Stage : First the necessary data collection Both depictions of the initial concept of the AINO application, The three data that have been collected are collected into the MySQL database, The fourth AINO application development using HTML and CSS, System Analysis Stage : Type the vehicle number platescan the barcode on the parking ticket select the type of vehicle wheel tapping the unique card on Aino exit the payment receipt that shows the value of the parking fee and the last balance is unique. Interview : At this stage the interviewees are supervisors, technicians and cashiers. With the topic of discussion of "parking system development" and the solutions obtained. Observation : I examined the airport exit gate accompanied by a cashier and technician. Literature study : Literature study is used to support the existing theoretical basis in writing the final project. Literature study is carried out to collect data or information by reading various kinds of literature books and articles written by experts related to the problem under study for experts related to the problem under study to get a theoretical and in-depth foundation and understanding. Systems Development Method, The following methods in system development are as follows: System Planning : First the necessary data collection, Both depictions of the initial concept of the AINO application, The three data that have been collected are collected into the MySQL data, The fourth AINO application development using HTML and CSS, System Analysis : Type the vehicle number plate, scan the barcode on the parking ticket, select the type of vehicle wheel, tapping the unique card on Aino, come out the payment receipt that shows the value of the parking fee and the last balance is unique. System Design : The contents include: vehicle plate number, barcode / card number, type of vehicle wheel. Then the nominal amount that must be paid by service users will appear. In this column contains : Card number, Bank, Payment, Ending balance, Bank nama, Total payment, Difference, System Implementation, The application is installed on a computer device where the device will be added with another device, which is used to make Payless payments. System Testing : The system test process, namely : Type the vehicle number plate, Ask for the type of payment, If you choose non-cash, then:

Scan the parking ticke, select the type of vehicle wheel, nominal appears, unique card tapping on the AINO system. Then a payment note will appear with the payment nominal, as well as the remaining balance on the unique card

\section{RESULT AND ANALYSIS}

In this application, it is very helpful to process the payment system quickly. So this system is considered 
International Journal of Computer and Information System (IJCIS)

Peer Reviewed - International Journal

Vol : Vol. 02, Issue 01, February 2021

e-ISSN : 2745-9659

https://ijcis.net/index.php/ijcis/index

successful in breaking down congestion on vehicles that want to leave the parking lot at the airport. The Management Information System is an integrated user machine system that provides information to support management operations and decision-making functions within an organization. The system makes use of computer hardware and software; and manual procedures; models for analysis, planning, monitoring and decision making and a data base. Payment system is a system that includes arrangements, contracts / agreements, operational facilities, and technical mechanisms used for the delivery, ratification and receipt of payment instructions, as well as the fulfillment of payment obligations through the exchange of "value" between individuals, banks and other institutions, both domestic and domestic. cross border "between countries". Electronic money is essentially cashless money, the value of which comes from the value of money first deposited to the issuer, then stored electronically in an electronic media in the form of a server (hard drive) or chip card, which functions as a non-cash payment instruments to merchants who are not electronic money issuers concerned. Online Web Application / Offline Application) In this analysis, AINO is an Online Web-based Application. AINO itself is an Online / Payless payment using cards such as Brizz y, Tap Cash, Flass and e-money. AINO was created using the HTML programming language and was modified or modified using the CSS programming language. HTML ( Hyper Text Markup Language) is a programming language used to create a web page. Meanwhile, CSS ( Cascading Style Sheet) is used to adjust the appearance in the HTML. The database used in AINO uses MySQL. MySQL was chosen because it is more suitable for web programming and is also more flexible to use for various programming languages.

\subsection{Computerized System Analysis}

The flow of the old system payment system, the cashier receives an entrance ticket (inside the entrance ticket, there is a vehicle number plate written manually), then it is transacted manuall, for parking fees determined from the time of entry and time out of service users.

\subsection{System Design}

The database used in AINO uses MySQL. MySQL was chosen because it is more suitable for web programming and is also more flexible to use for various programming languages

\subsection{System Implementation}

The database used in AINO uses MySQL. MySQL was chosen because it is more suitable for web programming and is also more flexible to use for various programming languages.

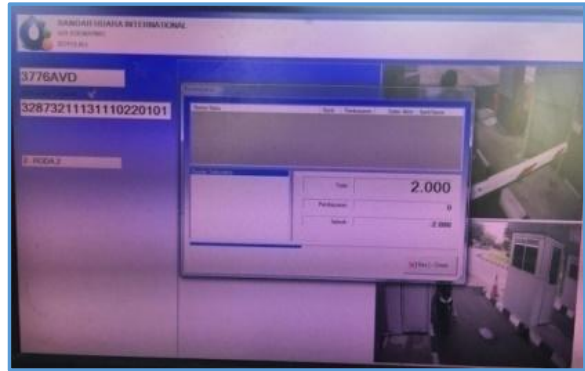

Figure 1. Input System

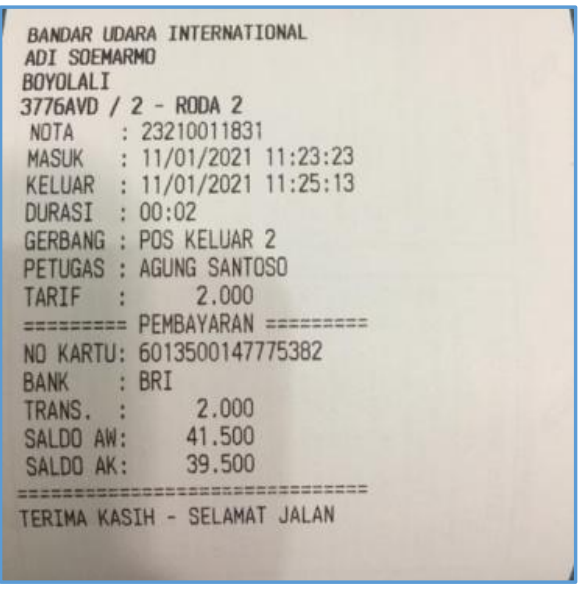

Figure 2. Aplikasi AINO

\subsection{System Testing}

Testing in the new system is done by means of the old system, only on the current system. Parking visitors at Adi Soemarmo Airport can make payments using Card / Noncash where previously they could only use cash only.

Table 1. Testing System

\begin{tabular}{|l|l|}
\hline Normal test & Test wrong \\
\hline $\begin{array}{l}\text { The system runs smoothly if the } \\
\text { vehicle number matches, the } \\
\text { type of wheel is suitable, the } \\
\text { balance contained in the u-nik } \\
\text { card is sufficient and the } \\
\text { internet connection is stable }\end{array}$ & $\begin{array}{l}\text { The system does not run } \\
\text { smoothly if the vehicle } \\
\text { number and wheel type } \\
\text { selection do not match. } \\
\text { Then if the balance is not } \\
\text { enough and the internet } \\
\text { connection is unstable }\end{array}$ \\
\hline
\end{tabular}

\section{CONCLUSION}

From the discussion in the previous chapter, it can be concluded that AINO plays an important role as a support for the parking payment system at Solo Airport. According to the survey, many people have made transactions, and with positive responses that the use of this system is running very smoothly, practically and efficiently. Of course, it is also very helpful for cashier performance and service user satisfaction when making transactions. From the conclusions that have been described above, the author can submit several suggestions as follow. In this application system there are still some shortcomings, for example only on an unstable internet connection or the chips on the u-nik 
International Journal of Computer and Information System (IJCIS)

Peer Reviewed - International Journal

Vol : Vol. 02, Issue 01, February 2021

e-ISSN : 2745-9659

https://ijcis.net/index.php/ijcis/index

card cannot be detected. Therefore, it is better if this application system is upgraded to a much better level, it is necessary to monitor or control the stability of the internet connection and check the chips on each u-nik card.

\section{REFERENCES}

[1] Muqorobin, M., \& Rais, N. A. R. (2020). Analysis of the Role of Information Systems Technology in Lecture Learning during the Corona Virus Pandemic. International Journal of Computer and Information System (IJCIS), 1(2).

[2] Muqorobin, M., Kusrini, K., Rokhmah, S., \& Muslihah, I. (2020). Estimation System For Late Payment Of School Tuition Fees. International Journal of Computer and Information System (IJCIS), 1(1).

[3] Solihin, Ahmad, MySQL 5 From Beginner to Advanced, Achmatim. net.

Jakarta. https://www.firebase.com/features.html, accessed September 26, 2015.

[5] Muqorobin, M., Rokhmah, S., Muslihah, I., \& Rais, N. A. R. (2020). Classification of Community Complaints Against Public Services on Twitter. International Journal of Computer and Information System (IJCIS), 1(1).

[6] Muqorobin, M., \& Rais, N. A. R. (2020, November). ANALISIS PERAN TEKNOLOGI SISTEM INFORMASI DALAM PEMBELAJARAN KULIAH DIMASA PANDEMI VIRUS CORONA. In Prosiding Seminar Nasional \& Call for Paper STIE AAS (pp. 157-168).

[7] Utomo, I. C., Rokhmah, S., \& Muslihah, I. (2020). Web Based Distribution of Zakat, Infaq, and shodaqoh (Case Study Of Surakarta City Region). International Journal of Computer and Information System (IJCIS), 1(1).

[8] K. Kusrini, E. T. Luthfi, M. Muqorobin and R. W. Abdullah, "Comparison of Naive Bayes and K-NN Method on Tuition Fee Payment Overdue Prediction," 2019 4th International Conference on Information Technology, Information Systems and Electrical Engineering (ICITISEE), Yogyakarta, Indonesia, 2019, pp. 125-130, doi: 10.1109/ICITISEE48480.2019.9003782.

[9] Muqorobin, M., Hisyam, Z., Mashuri, M., Hanafi, H., \& Setiyantara, Y. (2019). Implementasi Network Intrusion Detection System (NIDS) Dalam Sistem Keamanan Open Cloud Computing. Majalah Ilmiah Bahari Jogja, 17(2), 1-9.

[10] Muqorobin, M., Apriliyani, A., \& Kusrini, K. (2019). Sistem Pendukung Keputusan Penerimaan Beasiswa dengan Metode SAW. Respati, 14(1).

[11] Abdullah, Robi W., et al. "Keamanan Basis Data pada Perancangan Sistem Kepakaran Prestasi Sman Dikota Surakarta." Creative Communication and Innovative Technology Journal, vol. 12, no. 1, 2019, pp. 13-21.

[12] Saputra, R., \& Rais, N. A. R. (2020). Online Sales System Analysis of PT. Nutrifood Indonesia through the distributor CV. Trio Sukses Mandiri Solo With Nutrimart Home Delivery (NHD) Application. International Journal of Computer and Information System (IJCIS), 1(2).
[13] Muslihah, I., Muqorobin, M., Rokhmah, S., \& Rais, N. A. R. (2020). Texture Characteristic of Local Binary Pattern on Face Recognition with PROBABILISTIC LINEAR DISCRIMINANT ANALYSIS. International Journal of Computer and Information System (IJCIS), 1(1).

[14] Hikmah, I. N., \& Muqorobin, M. (2020). Employee Payroll Information System On Company Web-Based Consultant Engineering Services. International Journal of Computer and Information System (IJCIS), 1(2).

[15] Nastura, S. A., \& Muqorobin, M. (2020). Transaction Processing System Analysis Using The Distribution Management System (DMS) Nexsoft Distribution 6 (ND6). International Journal of Computer and Information System (IJCIS), 1(2). 